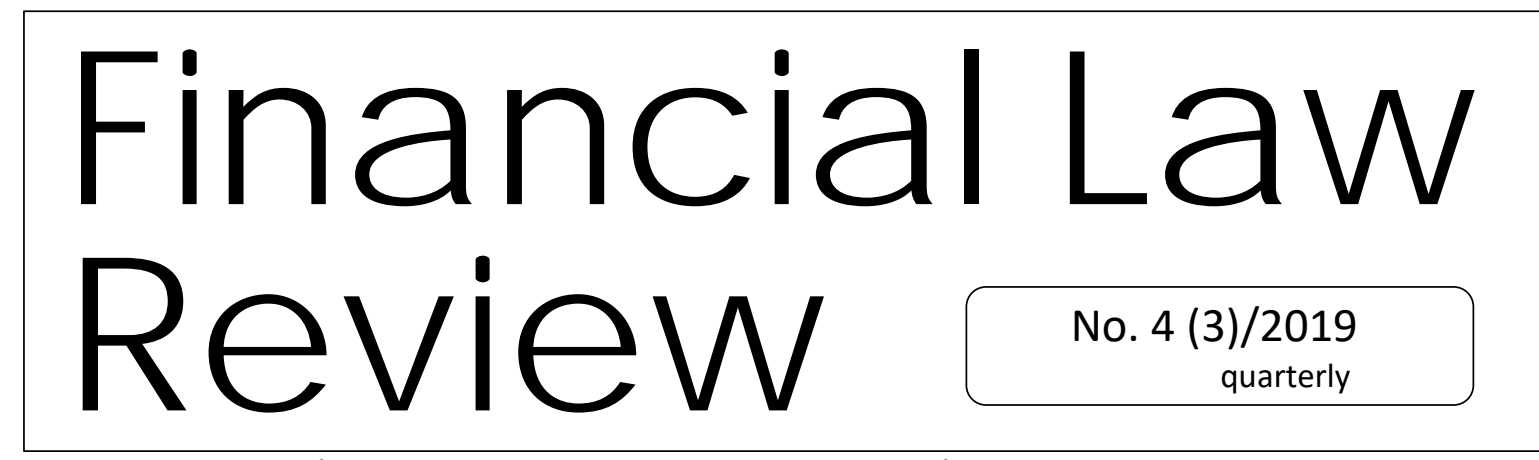

UNIVERSITY OF GDAŃSK • MASARYK UNIVERSITY • PAVEL JOZEF ŠAFÁRIK UNIVERSITY • UNIVERSITY OF VORONEZH http://www.ejoumals.eu/FLR

\title{
THE LEGAL ALLOCATION OF CURRENCY EXCHANGE RISK IN FOREIGN DIRECT INVESTMENT WAEL SAGHIR *
}

\begin{abstract}
Currency exchange risk is one of the major risks foreign investors may be exposed to while investing overseas. Such risk takes place when the host state's currency appreciates or depreciates in value affecting negatively the investor's investment. Since investors are concerned with losing the value of the host state's currency once an investment is made using that currency, it might be helpful for them to clearly understand when such risk occurs due to demand on the currency or due to manipulation of the host state in the exchange rates. For that, the paper clearly defines the nature of currency exchange risk in foreign direct investment where such financial risk may easily be regarded as a political one. The paper aims to add value through introducing a new approach in understanding the components that makes currency exchange risk considered as purely political risk or as purely financial. It aims to introduce the cases where such threat may be regarded as a political financial risk in order to assist investors in understanding what kind of a risk they could experience. The paper proves that currency exchange threat may take one of three
\end{abstract}

\footnotetext{
* PhD, Associate Editor of ISLRev and Visiting Lecturer at UK based institutions. Author specialized in international financial and investment law with list of publications including monographs, articles and conference presentations. An active member at the Society of Legal Scholars, LCIA and the Global Research Network Think Tank. Contact E-mail: wael.saghir@postgrad.sas.ac.uk.
} 
forms through examining nature of financial regulations in host states and through probing recent cases settled by ICSID.

Key words: Financial Regulation, Investment Risk, Currency Exchange

JEL Classification: P45

\section{Introduction}

As investment are increasingly interested in expanding overseas, their investments may be subjected to numerous risks that they wouldn't have necessarily encountered should they have not made the decision to go abroad. Normally investors may be subjected to three major risks; Political, Commercial and Financial risks. In terms of financial risk, investors could mainly be subjected to many threats one of which is currency exchange. For that, it is important to understand the true nature of this threat and to clearly distinguish between cases where this is regarded as a pure financial risk or as a political one. It is also of importance to understand how this risk could be a hybrid of both political and financial risks. To do so, this paper will resort to primary and secondary resources. Mainly, the paper will examine international treaties and two recent cases settled by ICSID. The first is the case of CMS v Argentina and the second one is Rusuro Mining v Venezuela. The paper will also examine the work of Rubins, Swan, Mora, Yescomb, Bishop and Saghir. Moreover, the paper will resort to news articles and peer-reviewed publications in order to prove the main hypothesis that exchange threat is one that could be considered as either a pure political risk, pure financial risk or as a political financial risk depending on the financial regulations of the host state and the amount of state intervention.

\section{Determents of Currency Exchange Rate}

In general, currency exchange rates are affected by the political situation of the host state and by its economic and fiscal policies. The sounder these policies are and the more stable the political situation is, the stronger the currency will be. A strong currency encourages investors to invest in a given state. The weaker the currency is, the more discouraged investors will be to invest in the host state using its currency. As such, investors are normally encouraged by the host state's limited intervention in determining currency's exchange rates.

Any given state may opt for one of three policies in determining how its currency preforms. This initially will either give investors the assurance they need to make their investment in the host state's currency or will make them reluctant in doing so. 
When looking at how the host state's currency is performing, it is advisable to understand the nature of the policy followed by host state. As such, the host state may opt to control its currency through pegging it to another one or it could manage it through monitoring it periodically or it could give markets the freedom to determine its value.

\section{a. Demand-Based Exchange Rate}

States that opted for a free-floating currency initially allowed exchange rate of their currency to be determined by the demand on it meaning that, demand is the driver in determining the value of the host state's currency [Bofinger \& Wollmershäuser 2001: 5]. In states like the United Kingdom and the United States and even in trade blocs that have unified currencies like the European Union, determining the value of their currencies was left to the markets [IMF 2017: 7].

In these states, what is notable is that government intervention is virtually non-existent [Blejer \& Leiderman 1979: 2]. In essence, this means the currency is behaving freely in the markets and the host state will not intervene in determining its value unless there was an underlying threat to the markets in which case it will intervene to evade such threat.

\section{b. Managed Exchange Rates}

There are states that opted for what is known as the dirty float or managed float policy in which the government intervenes in determining the market exchange rate. In these states, the government determines the limit of "floating" that the currency may be traded in [Bofinger \& Wollmershäuser 2001: 4]. States like China and Malaysia decided to determine the exchange rate path [IMF 2017: 9].

In these states, investors may be at risk once the hots state intervenes in determining the exchange rate in a manner that would affect the investor negatively.

\section{c. Controlled or Fixed Exchange Rates}

Some states opted for directly controlling their currency exchange rates in order to guard and protect their markets. These states decided to tie their currencies to a foreign one where the value of their local currency appreciates or depreciates depending on how the foreign currency is performing. In essence, this means that the currency's exchange rate is fixed to the one it is pegged to [IMF 2017: 10]. Such concept has historical grounds drawn within the Bretton Woods Agreement where other currencies were pegged to the US Dollar 
which in turn was pegged to gold [Lipsey 1975: 683-702]. States like Saudi Arabia and the UAE opted to peg their currencies to the dollar through determining a specific exchange rate that is constant against the dolar [IMF 2017: 6]. For example, the Saudi Riyal is pegged to the US Dollar where each US Dollar is equal to 3.75 Saudi Riyals whereas in the UAE, each US Dollar is equal to 3.6725 Dirhams [Al-Hamidy 2011: 301] and [Salama 2018]. On the other hand, Lebanon opted to for a stabilized arrangement whereby each US Dollar is equal to 1,507.5 Lebanese Pounds [IMF 2017: 61]. Such pegging could be considered another form of control over the currency and may present foreign investors with a layer of security while investing in the host state using the host state's currency but it, nevertheless, exposes them to other underlying risks such as currency manipulation.

Moreover, there are states, like Honduras and Nicaragua, that opted for what is known as a crawling peg whereby they revise and reassess periodically the value of the peg and change it as they deem suitable [Blejer \& Leiderman 1979: 2] and [IMF 2017: 6].

For that, it is of importance to differentiate between controlling a currency and manipulating it. Controlling refers to guarding the currency and ensuring its performance is stable in order to protect the currency and markets. Whereas manipulating refers to appreciating or depreciating the currency exchange rate in a deliberate manner by the host state in order to cause harm to foreign investors or to limit them from benefiting from their property rights in part or in full.

Investors who opted for investing in states that have pegged currencies using the host state's currencies my find their investments at risk if the host state decided to suddenly unpeg its currency causing harm to foreign investors as happened in Argentina in the early 2000s when the government decided unpegged the Peso from the US Dollar [Swan \& Murphy 1999: 52-54].

\section{Currency Exchange as a Threat to Foreign Investment}

Foreign investors who opted for investing in the host state using the host state's currency may find themselves, sometimes, at risk of losing the value of their investment due to the loss of currency's value. This risk, depending on the nature of its occurrence and the underlying facts that helped in its manifestation, could either be a pure political threat, pure financial threat or a hybrid of the two.

The importance in understanding the nature of this risk will help investors know exactly the type of threat they are encountering and how they could protect their investments against it through insurance or through undertaking other protective measures. 


\section{a. Currency Exchange as a Political Threat}

Generally, political risk can be defined as a threat to investments made by foreigners through means of interference by the host state's government or its representatives who are acting on its behalf resulting in limiting investors from benefiting from their property rights [Kobrin 67-68] and [Mora 2008: 80].

It requires a direct or indirect intervention by the host state in a manner that limits foreign investors from practicing and enjoying their property rights. Such risk generally includes acts like expropriation, nationalization and is influenced by the political environment of the host state in addition to the investor-state relationship and to the investment's sector [Jürgen 1982: 703].

Based on this brief introduction to political risk, it is understood that any action or underlying risk requires the intervention of the host state, or one of its representatives who's acting on behalf of the state and for its interest, to be regarded as a political risk. Failure to meet such condition means that the underlying risk may either be regarded as financial or commercial one.

In terms of currency exchange, for it to be considered as a political threat to investors, the host state needs to actively inflate or deflate the exchange rates of its currency [Howard 2013: 1216]. If the host state pegged its currency to a foreign one, like Argentina did between the 1990s and early 2000s, investors may be at risk of losing the value of their investment should the government decide to unpeg its currency [Swan \& Murphy 1999: 52-54]. In this scenario, the deliberate decision of the host state's government to unpeg its currency resulting in limiting foreign investors from benefiting from their property rights deliberately, such intervention in the currency exchange rate could be regarded as a pure political risk [Saghir 2018: 74-75]. This is for example what the US gas transmission company CMS experienced in Argentina.

\section{b. Currency Exchange as a Financial Threat}

Normally, currency exchange is one of the threats to foreign investors falling under the label of financial risk [Yescomb 2002: 183]. Financial risk in foreign investments are ones that are not directly related to the investment undertaken in the host state rather associated with external economic and financial factors of the host state itself [Saghir 2018: 71].

The UK's currency, the Pound Sterling, is a free-floating currency and its value is determined by the markets' demand [IMF 2017: 7]. The risk that investors encountered in the UK recently was the currency fluctuation that the Sterling experienced since the UK's decision to exit the European Union [Lee 2019], [Telegraph 2019] and [BBC Online]. The 
UK's government did not interfere in any way nor did attempt to manipulate the currency in order to keep it at a specific rate and as such, given the lack of intervention by the host state, losses that investors encountered due to the Sterling's fluctuation may only be regarded as a pure financial risk.

\section{c. Currency Exchange as a Political Financial Threat}

There may be instances where currency exchange risk may neither fall directly under the financial risk label nor the political risk classification since it shares qualities of both risks. As such, this threat, although it appeared due to direct intervention by the host state, it was not made for the purpose of depriving investors from their property rights. Rather intervention only took place in order to protect the host state's currency and markets.

In states that allowed its currencies to free float, like the Swedish Korona for example, government's intervention ranges from minimal to null depending on the markets performance [IMF 2017: 7]. Normally, these governments will not interfere unless there was a catastrophic event threatening the economic and financial stability of the state as the Swedish Central Bank recently declared [Martin 2016]. But this is, in fact, an exception to the rule.

In states that opted for the pegged currency policy, changes to the exchange rate or to the monetary policy may not necessarily be for the purpose of depriving investors, foreign or local, form their property rights rather could be undertaken to protect the local currency and markets. Indeed, the East Caribbean countries whose currency was once pegged to the Pound Sterling made the change and pegged the currency to the US Dollar due to increasing trade relationship with United States [Meissner \& Oomes 2008: 9].

In such cases, currency exchange threat may more accurately be regarded as a political financial risk given the host state's intervention in making the decision to unpeg the currency or to determine a specific ceiling which the currency is allowed to inflate or deflate within.

Similarly, in states where unofficial exchange markets were tolerated and relied on by investors where governments of these states decided later to deem such markets as illegal, such action may be regarded as a Political Financial Threat as is the case with Venezuela. 


\section{Currency Exchange and Investment Treaties}

Bilateral Investment Treaties [BITs] and Multilateral Investment Treaties [MITs] are means of promotion and protection of investors whereby states agree to offer investors of respective states a series of incentives that would allow them to facilitate their investments.

Normally, these treaties include clauses aimed at limiting expropriation of investors' properties, means of compensation, National Treatment, Fair and Equitable Treatment, Treatment no Less Favorable than that awarded to investors of other states in addition to other clauses in which investors are offered specific rights when it comes to remitting their earnings among others [Bishop, Crawford \& Reisman 2005: 10].

When it comes to currency exchange and transfer, one of the examples can be found in the BIT between the Kingdom of Denmark and the Bolivarian Republic of Venezuela whereby in Article 7 of this treaty the parties agreed to allow the free transfer of capital and proceeds of the investment [Denmark and Venezuela BIT 1994: Art 7]. It also drew the line when it comes to transfer of currency where currency may be convertible on the basis of the market rate on the date of the transfer [Denmark and Venezuela BIT 1994: Art 7].

Additionally, article VIII of the BIT between Venezuela and Canada, awarded investors the right to freely transfer the investment funds in the currency of which the investment was originally made with or in any convertible currency the contracting state and the investor agrees on and in the rate of exchange applicable on the date of transfer [Canada and Venezuela BIT 1996: Art VIII].

When investors experience losses to their property rights in the host state, they resort to the International Centre for Settlement of Investment Disputes [ICSID] to settle any disputes arising between them and host states in relation to the proper application or interpretation of BITs or an MITs.

The following examples are recent cases settled by ICSID in which at least one of the claims made by the Claimants was related to Currency Exchange or Transfer.

\section{a. Rusoro v Venezuela}

When a Canadian registered company acquired the rights of a number of gold mining sites in Venezuela through owning the company which held the mining rights in Venezuela, Rusoro did not anticipate the forthcoming changes in law within Venezuela that eventually led to the nationalisation of the gold mining sector as a whole. 
Among the claims against Venezuela submitted to ICSID, Rusoro stated that it suffered losses from the Currency Exchange rate introduced by the Central Bank of Venezuela [Rusoro Mining v Venezuela 2016: Sec D, Para 456].

These losses, according to the company, amounted due to the artificially boosted value of the Venezuelan Bolivar and due to the abolishment of the Swap Market, a currency exchange market which was tolerated by the Venezuelan government until the introduction of the new law which made activities in this market illegal [Rusoro Mining $\mathrm{v}$ Venezuela 2016: Sec D, Para 424, 454-455 \& 484].

Additionally, Venezuela implemented a number of restrictions on exporting gold putting private companies at a disadvantage compared to public companies. Although the government re-introduced no legislation equalising the treatment of gold exporting companies irrespective of its ownership structure.

The important factor in this case in relation to Currency Exchange and Transfer was the Tribunal's analysis where the Tribunal agreed that "States have the sovereign right to establish and amend, in furtherance of their economic policy, exchange control regulations which defines the relationship between the State's own currency and that of other sovereigns" [Rusoro Mining v Venezuela 2016: Para 531].

This case represents an example of how Currency Exchange may be considered as a Political Financial Risk given that the host state changed its regulatory framework to rely on the official rate introduced by the Central Bank rather than allowing investors to use a gray market that determine the currency exchange rates on different merits.

\section{b. CMS v Argentina}

In light of the economic hardship Argentina was experiencing, the government decided to suspend some of the incentives awarded to foreign investors and to unpeg the Argentine Peso from the US dollar.

Additionally, some of the incentives awarded to foreign investors in public utilities by the Argentinian Government was their right to adjust tariffs according to the US Producer Price Index [US PPI] biannually and to calculate tariffs in US dollar whereby the rate of the Argentine Peso to the US dollar was pegged on the basis of 1 to 1 .

This, however changed due to the economic situation since these incentives were halted resulting in losses on part of foreign investors like CMS the US Gas Transmission Company and resulting in severe flight of foreign capital [CMS v Argentina 2005: Para 65, $69-73,164 \& 168]$. This is especially true since the rate of the Argentine Peso after it 
became unpegged to the dollar was valued at 3 Pesos per Dollar. The underlying issue here was calculating the tariffs where these were calculated in Peso the adjusted according to Argentina's Consumer Price Index and then later converted to US dollar and subjected to the dollar adjustment in accordance with Argentina's Convertibility Law of 1991 [CMS v Argentina 2005: Para 130].

What is notable is that the Tribunal saw that it does not have the authority to decide whether the economic policies enacted by Argentina were right or wrong rather it aims to examine whether these measures resulted in "adverse consequences" for the CMS [CMS v Argentina 2005: Para 159].

In its decision, the Tribunal found that the BIT between Argentina and the US stipulates that parties to this treaty are to respect any legal and contractual obligation connected to an investment [USA and Argentina BIT 1991: Art. II(2)c]. In that respect, the incentives that Argentina awarded to investors, including tariff incentives, was considered as legally binding and as such, not respecting such obligations is in violation of Article II(2)c [CMS v Argentina 2005: Para 303].

This case is an example of how currency exchange could be regarded as a Pure Political Risk given the fact that Argentina decided to unpeg its currency and suspend the special treatment awarded to foreign investors through changing and suspending laws governing special tariffs and exchange rates. And although, it is up to the host state to decide on its financial and economic policy in any way it deems appropriate, the fact that Argentina did not adhere by and respect the contractual obligations it made with investors means that such risk is a Pure Political Risk.

\section{Conclusion}

Currency exchange fluctuation pauses a threat to foreign investors. As such, understanding the nature of the monitory policy followed by the host state will assist investors understand the exact type of risk they could encounter. The paper thoroughly examined different host state approaches in regard to currency exchange and proved that currency exchange threat could form one of three risks.

Classically currency exchange fluctuation was regarded as financial risk, but the view changed after the crisis in Asia and Latin America [Rubnis \& Kinsella 2005: 18]. Currency exchange rate fluctuation may now be either political or financial risk or it could also be a hybrid of the two.

For that, it is equally important to understand the limit of host state's intervention in determining the currency exchange rate where the host state may decide to actively control 
the currency through inflating or deflating it like the Venezuelan government did [Ulmer and Corina Pons 2018]. In such states currency exchange is considered a political risk.

It could also decide to manipulate with the currency exchange rate through artificially increasing or decreasing the value of the currency in order to limit investors form benefiting from their property rights like Argentina did. Such action is regarded as a political risk. On the other hand, manipulating with the currency exchange rate may not necessarily be for the purpose of depriving investors from their property rights rather could be to drive the host state's growth higher like what China did with the US Dollar recently, for example [Skaff, Webb \& Clahane 2018: 1-4] and [Wallace 2018]. In such case, the currency exchange here may be regarded as a political financial risk.

Alternatively, intervention means that the host state will step in to protect its currency and markets in order to evade a catastrophic or eminent threat to the currency or to its market or may be taken as an answer to a crisis that is in the shaping or one that already took place [Bank of Cleveland 2003: 3-4]. This is for example what happened in Greece in 2008 where the government imposed currency controls until 2016 in response to the financial crisis the country experienced [Smith 2016]. In such scenarios, currency exchange threat may be regarded as a political financial risk.

Finally, it can be concluded that the key to finding out the exact nature of currency exchange threat lies in understanding the nature and degree of the host state's intervention in currency exchange rates and the monitory policy the state follows.

\section{References:}

'Government Intervention in the Foreign Exchange Market', Federal Reserve Bank of Cleveland (November 2003), Working Paper 03-15.

Al-Hamidy, A., "Monetary policy in Saudi Arabia", BIS Papers No 57, (October 2011).

Annual Report on Exchange Arrangements and Exchange Restrictions 2017, International Monetary Fund (2017).

Bishop, R.D., Crawford, J. and Reisman, W.M., Foreign Investment Disputes: Cases, Materials and Commentary (Kluwer Law International 2005).

Blejer, M.I., and Leiderman, L., 'A Monetary Approach to the Crawling-Peg System: Theory and Evidence', Boston University Center for Latin American Development Studies, (January 1979) Discussion Paper Number 30.

Bofinger, P., and Wollmershäuser, T., 'Managed Floating: Understanding the New International Monetory Order', Würzburg Economic papers No. 30, (2001) University of Würzburg Lehrstuhl für VWL 1. 
Howard, L., 'Chinese Currency Manipulation: Are there Any Solutions?', Emory International Law Review (2013)

IMF Annual Report in Exchange Arrangements and Exchange Restrictions, (IMF 2017)

Jürgen, K., 'The Protection and Promotion of Foreign Direct Investment in Developing Countries: Interests, Interdependencies, Intricacies' (1982) 31 International and Comparative Law Quarterly.

Kobrin, S.J., 'Political Risk: A Review and Reconsideration' 10 Journal of International Business Studies.

Lipsey, R.G, An introduction to positive economics (4th edn. Weidenfeld \& Nicolson 1975).

Meissner, C.M., and Oomes, N., 'Why Do Countries Peg the Way They Peg? The Determents of Anchor Currency Choice', International Monetary Fund Working Papers WP/08/132 (May 2008),

Mora, T.H (ed), International Political Risk Management: Exploring New Frontiers, (World Bank 2001).

Reeves W.H., '"Expropriation,"'Confiscation,"'Nationalization" What One Can Do About Them' (1969) 24 The Business Lawyer.

Rubnis, N., and Kinsella, K., International Investment, Political Risk, and Dispute Resolution: A Practitioner's Guide (Oxford University Press, USA 2005).

Saghir, W., Foreign Direct Investment Risks and Export Credit Agencies: A Practitioner's Guide, (Wildy, Simmonds \& Hill 2018).

Skaff, R., Webb, L., and Clahane, K., 'Understanding China’s Currency Manipulation’ Bush School of Government and Public Services, Mosbacher Institute (2018), Volume 9, Issue 1.

Swan, A.C., and Murphy, J.F., Cases and Materials on the Regulation of International Business and Economic Relations (Matthew Bender and Company 1999).

Yescomb, E.R., Principals of Project Finance, (2nd edn. Elsevier 2002).

\section{International Treaties:}

Agreement between the Government of Canada and the Government of the Republic of Venezuela for the Promotion and Protection of Investment (1996)

Agreement Between the Government of the Kingdom of Denmark and the Government of the Republic of Venezuela Concerning the Promotion and Reciprocal Protection of Investments (1994)

Treaty between United States of America and the Argentine Republic Concerning the Reciprocal Encouragement and Protection of Investment (1991) 


\section{Cases:}

Rusoro Mining Limited $v$ The Bolivarian Republic of Venezuela (Award 2016) ICSID Case No. $\operatorname{ARB}(\mathrm{AF}) / 12 / 5$.

CMS Gas Transmission Company $v$ The Argentine Republic (Award 2005) Case No. $\mathrm{ARB} / 01 / 8$.

\section{News Articles and Internet Resources:}

BBC News Online at: https://www.bbc.com/news/topics/cx250jmk4e7t/pound-sterlinggbp, Last accessed on the 13th of April 2019.

Central Bank of Lebanon: http://www.bdl.gov.lb/webroot/statistics/table.php?name=t5282usd, Last accessed on the 12th of April 2019.

How Will Brexit Impact the Pound?, Telegraph Financial Solutions, Telegraph Online (26 March 2019). Found at: https://www.telegraph.co.uk/financial-services/currencyexchange/international-money-transfers/pound-forecast-post-brexit/, Last accessed on the 12th of April 2019.

Lee, Y.N., 'Don't Buy the British Pound Yet, Experts Say Brexit Risks Still Loom', CNBC (16 January 2019). Found at: https://www.cnbc.com/2019/01/16/brexit-dont-buybritish-pound-sterling-investment-experts-say.html, Last accessed on the 12th of April 2019.

Martin, K., 'The Riksbank's Roadmap to Currency Intervention', Financial Times (18 January 2016). Found at: https://www.ft.com/content/d7dbb59c-24f0-3557-aaba$\underline{080 \mathrm{~b} 023 \mathrm{~d} 0 \mathrm{~d} 83}$, Last accessed on the 12th of April 2019.

Salama, S., "Governor says UAE will keep dirham tied to US dollar", Gulf News, (30 January 2018), https://gulfnews.com/business/banking/governor-says-uae-will-keepdirham-tied-to-us-dollar-1.2165649, Last accessed on the 12th of April 2019.

Smith, H., 'Greece Eases Back on Capital Controls in Bid to Reverse Currency Flight' The Guardian Online (1 August 2016). Found at:

https://www.theguardian.com/world/2016/aug/01/greece-ease-capital-controlsreverse-currency-flight-eurozone, Last accessed on the 13th of April 2019.

Ulmer, A., and Pons, C., 'Maduro Orders 96 Percent Devaluation in Hyperinflationstricken Venezuela', Reuters (18 August 2018). Found at:

https://www.reuters.com/article/us-venezuela-currency/maduro-orders-96-percentdevaluation-in-hyperinflation-stricken-venezuela-idUSKBN1L22EZ, Last accessed on the 13th of April 2019.

Wallace, C., 'China's Currency Manipulation is a Response to Trump's Tariffs', Forbes (21 July 2018). Found at:

https://www.forbes.com/sites/charleswallace1/2018/07/21/chinas-currencymanipulation-is-a-response-to-trumps-tariffs/\#21f9fa2c663b, Last accessed on the 13th of April 2019. 